\title{
Valuation Channel and Losses of Chinese External Wealth
}

\author{
Zefang Liao ${ }^{1,2}$, Jianpeng Zhang ${ }^{1}$, Bing $\mathrm{Li}^{1,3}$ \\ ${ }^{1}$ Financial Research Center Fudan University, Shanghai, China; ${ }^{2}$ Guangdong Ocean University, Zhanjiang Guangdong, ${ }^{3}$ China; \\ School of Economics and Business Administration, Shanxi University, China.
}

Received May, 2013

\begin{abstract}
Based on the intertemporal theoretical framework of Gourinchas and Rey ( 2005), using Vector Error Correction Model and time-varying Space State Model, the paper estimates the return and factors of China's net foreign assets. The results show that significant negative valuation effects in the change of net foreign assets and its sub-category, "risk assets", especially at short and medium horizons. The fluctuation of assets prices arising from international financial crisis and appreciation of RMB contribute to the losses of external wealth, implying much wealth outflow to other economies.
\end{abstract}

Keywords: Capital Flows; Net Foreign Assets; Valuation Effects

\section{Introduction}

The rapid growth in cross-border financial trade has been one of the salient economic developments over the last two decades. And new questions arise from this. First, the fact is that capital tends to flow uphill-from poor to rich countries rather than the other way round, a phenomenon known in the literature as the "Lucas Paradox". [1] Second, it is increasingly well appreciated that capital gains and losses on existing holdings of foreign assets and liabilities can be important in determining the dynamics of the net foreign assets position, so much wealth are transferred across different economies.

The recent experience of some countries provides illustrations of capital gains and losses on cross-border flows. For example, cumulative debt inflows in Argentina measured US $\$ 7.9 \mathrm{bn}$ between 1977 and 1981, While the debt stock(net of the effect of currency fluctuations) increased by US $\$ 24.8 \mathrm{bn}$, a difference of over $20 \%$ of Argentina's 1981 GDP. [2] More recently, During 20022007 , despite average current account deficit of over $5 \%$ of GDP, the U.S. net international investment position (IIP)--which measures the difference between U.S. external assets and liabilities - has remained broadly unchanged. ${ }^{1}[3]$

What explains these remarkable differences? Based on the measure of external wealth (Lane and Milesi-Ferretti, 2001), Some recent strand of the literature emphasizes the role of valuation effects in the process of external wealth (Gourinchas and Rey, 2005, 2007a; Lane and Milesi-Ferretti,2005, 2007; Obstfeld,2004).[4]

\footnotetext{
${ }^{1}$ Net external liabilities measured with FDI at current cost are unchanged as a ratio of GDP between 2001and 2007, while net liabilities measured at market value have actually in absolutes terms.
}

Under the current international monetary system, valuation effects play different roles across countries in international financial markets. In developed countries, where foreign assets tend to be denominated in foreign currency and liabilities in domestic currency, thus valuation effects arising from unexpected depreciation of domestic currency would increase the domestic currency value of foreign assets and with the value of liabilities unchanged-net foreign assets improve exhibiting positive valuation effects. For example, during U.S. current account correction of 1985-1988, the U.S. dollar depreciated by about $30 \%$ in real effective terms. More recently, the valuation adjustments associated with the U.S. dollar depreciation during 2002-2004 have offset about threefourths of the cumulative U.S. current account deficit over the same period. [5] Over a longer horizon, the stabilizing valuation effects contribute as much as $31 \%$ of U.S. external imbalance adjustment during 1980-2003 (Gourinchas and Rey, IMF, 2005). [6] With large gross asset and liability positions, a change in the dollar exchange rate can transfer large amount of wealth across countries. As documented by Gourinchas and Rey (2007a) and Lane and Milesi-Ferretti (2007b), these capital gains imply that the return earned by U.S. residents on their external assets is significantly higher than the return earned by foreign residents on U.S. assets. $[7,8]$ The similar cases occurred in U.K. and Canada, positive valuation effect accounted for about $20 \%$ the change of Canada's net international position to GDP in 2004, and valuation represented about $50 \%$ of U.K.'s GDP in 2000 , even exceeding the impact of current account on international position (Gourinchas and Rey, IMF, 2005). Currency depreciation in these countries where external 
wealth have been to improve- that is equivalent to a wealth transfer from other countries [6].

Whereas in emerging market and developing countries, where most foreign assets and liabilities tend to be denominated in foreign currency, valuation effects arising from unexpected exchange rate appreciation are likely to deteriorate their international position - most are negative valuation shocks because of currency mismatch. For example, during1992-2001, current account surplus to GDP accounted for $32.9 \%$ and $11.9 \%$ of Indonesia and Thailand respectively, but the losses to net international position from valuation represented $39 \%$ and $21.9 \%$ of their own GDP over the same period [9].

According to measurement on Net Foreign Asset (NFA) of Lane and Milesi-Ferretti (2001), China had turned into the holder of NFA since in the early 1990s, and now it is one of the biggest global creditor. But due to unrealized RMB internationalization, China is still an immature creditor country, ${ }^{2}$ whose external wealth is facing with risk of large losses, especially in the expectation of RMB revaluation and fluctuation of international financial asset prices. How about the gain or losses on China's external wealth? The paper will focuses on this question.

In this paper, my methodology builds on the working paper of Gourinchas and Rey(2005)in NBER, aiming to investigate the relation among net external wealth, export and import, and the real exchange rate of China, making use of a new data set on external assets and liabilities constructed by Lane and Milesi-Ferretti (2001) [2].

The remainder of the paper is structured as follows. In section 2 I provide the theoretical framework that used for empirical investigation of the mechanisms of valuation effect on net external wealth. I explore the construction of annual and quarterly dataset of China's net foreign assets and its sub-category, "risk assets" position at statistical values in section 3. Empirical results are presented in the section 4 . First, we estimates valuation effect to annual external wealth of China, then the "risk assets" are evaluated in the model. Section 5 concludes.

\section{Theoretical Framework and Implication}

According to the dynamic model of net foreign asset of Gourinchas-Rey (2005) and Lane, P., Milesi-Ferretti (2007), $[5,8]$ this section lays down an intertemporal approach to the cumulative net foreign net (external wealth): an intertemporal budget constraint and a long-run stability condition.

Account for the dynamic accumulation equation between $\mathrm{t}$ and $t+1$ :

\footnotetext{
${ }^{2}$ Ronald Mckinnon(2009) called those countries who can't provide finance to other economies with their own currencies as immature countries.
}

$$
\begin{aligned}
& N F A_{t+1}=R_{t+1}\left(N F A_{t}+N X_{t}\right) \\
& =R_{t+1}\left[\left(A_{t}-L_{t}\right)+\left(X_{t}-M_{t}\right)\right] \\
& N F A_{t}=A_{t}-L_{t} ; N X_{t}=X_{t}-M_{t}
\end{aligned}
$$

$N F A_{t}$ and $R_{t}$ represent net foreign assets and their gains, and $N F A_{t}$ are defined as the difference between gross foreign assets $A_{t}$ and gross foreign liabilities $L_{t}$, net exports $N X_{t}$ are defined as the difference between the volumes of exports $X_{t}$ and imports $M_{t}$ of goods and services, measured in U.S. dollar. ${ }^{3}$ Divide through GDP, identity (1) transform to:

$$
\begin{aligned}
& \frac{N F A_{t+1}}{G D P_{t+1}} \frac{G D P_{t+1}}{G D P_{t}} \\
= & R_{t+1}\left[\left(\frac{A_{t}}{G D P_{t}}-\frac{L_{t}}{G D P_{t}}\right)+\left(\frac{X_{t}}{G D P_{t}}-\frac{M_{t}}{G D P_{t}}\right)\right]
\end{aligned}
$$

To discuss further the implication of equation (2) and log-linearize. The log-linearization requires the following assumptions:

i) $\mathrm{R}$ and Ratios $\frac{N F A_{t+1}}{G D P_{t+1}}, \frac{G D P_{t+1}}{G D P_{t}}, \frac{A_{t}}{G D P_{t}}, \frac{L_{t}}{G D P_{t}}$, $\frac{X_{t}}{G D P_{t}}, \frac{M_{t}}{G D P_{t}}$ are stationary. ii) $\frac{G D P_{t+1}}{G D P_{t}}=\mathrm{g}$, and R > $\mathrm{g}$, 令 $\frac{g}{R}=\lambda<1, \frac{N X_{t}}{N F A_{t}}$ satisfies: $\frac{N X_{t}}{N F A_{t}}=\lambda-1<0$.

Following the methodology of Corsetti and Konstantinou(2004) and Gourinchas and Rey (2005), [5,6]it is possible to derive the following log-linear approximation of equation(1):

$$
\begin{aligned}
& x_{t}-\gamma m_{t}+(\gamma-1) n f a_{t} \\
= & \sum_{i=1}^{\infty} \rho^{i}\left[\Delta x_{t+i}-\gamma \Delta m_{t+i}+(\gamma-1) r_{t+i}\right]
\end{aligned}
$$

Where lowercase letters denote logarithms. ${ }^{4}$

Equations (3) play a central role in my analysis. Under the assumptions that $r_{t}, \Delta x_{t}$ and $\Delta m_{t}$ are stationary, expression (3) implies that $\mathrm{x}, \mathrm{m}$ and nfa should be cointegrated, and the left-hand side (the cointegration residual) represents deviations from the long-run relationship among three variable. Expression (3) also implies that if the cointegrating residual is not a constant, it has to predict either changes in the future net exports or in net foreign returns or both. For example, if a country develops a large trade surplus relative to what is consistent with its steady-state net foreign assets position, the deviation from the long-run relationship has to be adjusted either by decrease in future net exports or by fu-

\footnotetext{
${ }^{3}$ Accumulation equation (1) implies that $N F A_{t}$ are measured at the beginning of the period. One could instead define $N F A^{\prime}{ }_{t}$ as the stock of net foreign assets at the end of period t-1, so $N F A_{t}=R_{t} N F A_{t}^{\prime}$. The dynamic accumulation equation becomes: $N F A_{t+1}^{\prime}=R_{t} N F A_{t}^{\prime}+N X_{t}$.

${ }^{4}$ In expression(4), $\gamma$ and $\rho$ are constants related to the log-linearization of the country's intertemporal budget constraint(see Corsetti and Konstantinou, 2004).
} 
ture losses on the stock of its foreign assets and liabilities, or a combination of the two. The latter are valuation effects. If valuation of some economy's NFA is positive, implying a wealth transfer from other countries through international financial channel, which makes net foreign asset increased or net foreign liability decreased. On the contrary, if valuation of some economy's NFA is negative, implying a wealth outflow to other countries through international financial markets, which makes net foreign asset decreased or net foreign liability increased. Consider the case of the China with both a large trade surplus and positive net foreign assets, negative valuation of net foreign assets implying vast losses of external wealth.

\section{International Assets Position}

In this section, I describe briery the construction of my dataset. All data are available from IMF's International Financial Statistics. Export and import is flowing asset, net foreign asset and "risk assets" are cumulative assets. These assets are measured in US $\$$ million. Use nominal effective exchange rate $(2005=100)$ as $\mathrm{RMB}$ exchange rate. Select annual data for the period 1991-2010, quarterly data for the period 1981Q1-2010Q4 as sample, take 1981 (or 1981 Q1) as initial period of cumulative assets.

Following official classifications, I split China's net foreign asset into four categories: Foreign Direct Investment (FDI), Portfolio Investment Assets (Equity Securities and Debt Securities), Other Investment Assets and Reserve Assets (including gold reserves). "Risk assets" calculated as cumulative Other Investment Assets and Reserve Assets.

Denote by $X_{t}^{\prime}$ the end of period t position for some asset $\mathrm{X}$. Use the following updating equation:

$$
X_{t}^{\prime}=X_{t-1}^{\prime}+F X_{t}+D X_{t}
$$

where $F X_{t}$ denotes the flows corresponding to asset $\mathrm{X}$ that enter the balance of payments, and $D X_{t}$ denotes a discrepancy reflecting a market valuation adjustment or (less often) a change of coverage in the series between periods $\mathrm{t}-1$ and $\mathrm{t}$.

Our constructed series of the net foreign asset position for China is shown in Figure 1, measure as ratio to GDP. We see a distinct increase of China net foreign asset position after 1990. China switched from being a net debtor

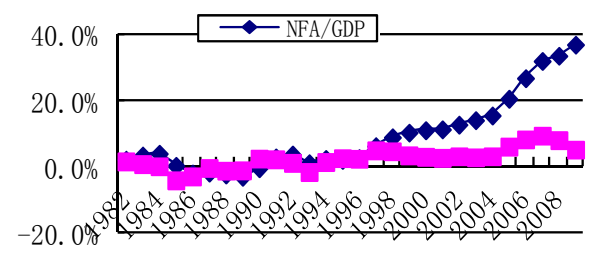

Source: IMF's International Financial Statistics.

Figure 1. Net Foreign Asset position and Net Exports (\% of GDP), China, 1981-2009. to being a net creditor around 1991 and its net foreign asset position has kept on improving ever since.

\section{Empirical Results}

Section 3 showed that under some stationary assumptions, a linear combination of $x_{t}, m_{t}, n f a_{t}$ is theoretically well-defined measure of returns of external wealth. In this section, I will make empirical examination for valuation effects of annual net foreign assets and quarterly "risk assets", and explore the relation between dynamic change of valuation effects and RMB exchange rate. X, M, NFA and NFAR represent export, import, net foreign assets and "risk assets" of net foreign assets.

\subsection{Net Foreign Assets and Valuation}

Empirical implementation proceeds in two methods. Using Vector Error Correction Model estimates annual average valuation effects of nfa during 1981-2010. Then I estimate the trend of annual valuation effects through time-varying State Space model.

First I test for unit root in (log) net foreign assets, exports, imports. Augmented Dickey Fuller (ADF) tests overwhelmingly support the presence of unit roots in each of the three series, nfa is $I(1)$ steady process, $x$ and $\mathrm{m}$ are $\mathrm{I}(2)$ steady process.

Second, I check the empirical validity of stationarity assumption, implying that cointegrating relation among $x_{t}, m_{t}$ and $n f a_{t}$. Using Johansen-Jueselius test (see Johansen, 1991, 1995), the results shows that, there are cointegrating relation among these three variables, and the Trace Statistic and maximum eigenvalue statistic approve the only cointegrating equation.

The third step is to estimate the cointegrating vectors. Using Vector Error Correction Model (VECM), it could be estimated the following equation:

$$
\begin{aligned}
\Delta \mathrm{nfa}= & -0.523 \mathrm{VECM}(-1)-0.013 \Delta \mathrm{nfa}(-1)-0.358 \Delta \mathrm{nfa}(-2) \\
& (-2.74) \quad(-1.05) \quad(-2.34) \\
& -3.113 \Delta \mathrm{x}(-1)+1.133 \Delta \mathrm{x}(-2)+3.179 \Delta \mathrm{m}(-1) \\
& (-1.95) \quad(2.89) \quad(2.05) \\
& +0.159 \Delta \mathrm{m}(-2)+0.255 \\
& (2.13) \quad(1.16) \\
& \mathrm{R}^{2}=0.66, \quad \mathrm{~F}=2.23, \operatorname{LogL}=8.49
\end{aligned}
$$

Note: $\operatorname{VECM}(-1)$ represents the long-run cointegrating residual of the first-order lag, t- statistic in parenthesis.

Expression (5) indicates that, during 1991-2009, valuation of China's net foreign assets is -0.523 , and $t-$ statistic is 2.74 , the estimated result is valid. So, in the past two decades, Expression (5) also shows that the change of China's net foreign assets have considerable negative valuation effects, implying substantial losses of net foreign assets and a wealth outflow to other countries.

Through variance decomposition to $\mathrm{nfa}$, it can predict 
the future factors of nfa, showing in Table 1. The results imply that the share of the variation in net foreign assets explained by transitory shocks at a one-year horizon is over $90 \%$. Valuation plays a very important role for change of China's external wealth in short and medium period.

For the purpose of estimating dynamic trend of China's net foreign assets, I use time-varying State Space model for further analysis. First, I estimate the following equation by OLS:

$$
\begin{aligned}
n f a_{t}= & 1.573 x_{t}-0.463 m_{t}+\hat{u}_{t} \\
& (7.86) \quad(-2.30)
\end{aligned}
$$

Define $\mathrm{ECM}=\hat{u}_{t}$, and according to the research of Hamilton (1994), time-varying State Space Model can be made as follows:

Measurement equation:

$$
\mathrm{D} n f a_{t}=\mathrm{c}_{1} * \mathrm{D} x_{t}+\mathrm{c}_{2} * \mathrm{D} m_{t}+\mathrm{SV}_{1 \mathrm{f}} * \operatorname{ECM}(-1)+\mathrm{v}_{\mathrm{t}}
$$

State equation: $\mathrm{sv}_{1 \mathrm{f}}=\alpha_{0}+\alpha^{*} \mathrm{sv}_{1 \mathrm{f}-1}+\mathrm{v}_{1 \mathrm{t}}$

Where $\mathrm{v}_{\mathrm{t}}$ and $\mathrm{v}_{1 \mathrm{t}}$ are independent continuous disturbance term whose mean value is $0, \mathrm{c}_{1}, \mathrm{c}_{2}$ are fixed coefficient, and $\mathrm{SV}_{1 \mathrm{f}}$ is time-varying parameter. And $\mathrm{SV}_{1 \mathrm{f}}$ is regarded as the dynamic valuation effects in the paper, and the estimated results of $\mathrm{SV}_{1 \mathrm{f}}$ are shown in Figure 2. The figure shows that $n f a_{t}$ predicted a relatively high losses on the net foreign asset portfolio of China except for 1995 and 1999, especially in 1993 and during financial crisis of 1997-1998 and 2007. So the fluctuation of assets arising from international financial market would also deteriorate China's external wealth.

Table 1. Variance Decomposition of nfa.

\begin{tabular}{ccccc}
\hline Period & S.E. & $n f a$ & $x$ & $m$ \\
\hline 1 & 0.201 & 100.00 & 0.00 & 0.0000 \\
2 & 0.254 & 92.00 & 7.99 & 0.0009 \\
3 & 0.415 & 60.56 & 39.19 & 0.2561 \\
4 & 0.484 & 53.99 & 45.46 & 0.5536 \\
5 & 0.562 & 44.33 & 54.81 & 0.8642 \\
6 & 0.621 & 39.66 & 59.45 & 0.8891 \\
7 & 0.649 & 37.98 & 61.11 & 0.9105 \\
8 & 0.665 & 38.33 & 60.75 & 0.9256 \\
\hline
\end{tabular}

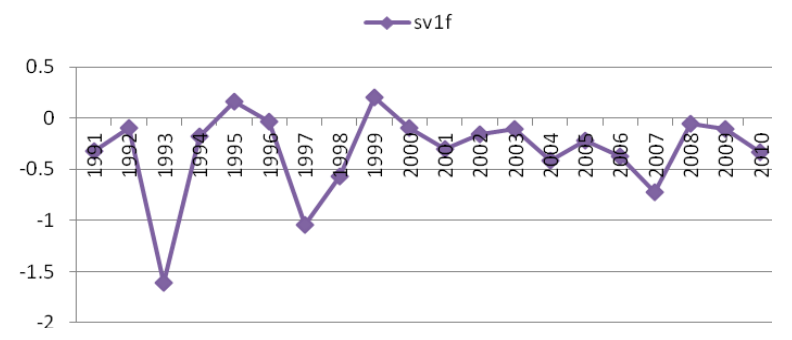

Figure 2. 1991-2010 dynamic valuation effects of China's net foreign assets.

\subsection{External Risk Assets and RMB Exchange Rate}

For further assessing the dynamic relation between net foreign assets and RMB exchange rate, exploring through quarterly dataset. Because of lacking quarterly data about FDI and Portfolio Investment Assets, and the "risk assets" which composed of Other Investment Assets and Reserve Assets are more affected by fluctuation of interest rate, exchange rate and the prices of assets. The return of "risk assets" is the most key composition of valuation effects. So it only analyzes variation tendency of "risk assets" in this part. Using the similar method of estimation, valuation effects of the "risk assets" SV2f are shown in Figure 3. The figure shows that $n f a r_{t}$ predicted negative returns between -0.45 and -0.15 , implying official reserve and Other Investment Assets have negative effects of wealth variable.

Aim to investigate the dynamic relation between China's nfar and RMB exchange rate, using OLS, the following equation is estimated:

$$
\begin{aligned}
\text { SV2f }= & -0.285+0.184 \Delta \text { LNNEER } \\
& (-107.9) \quad(3.77)
\end{aligned}
$$

$\mathrm{DW}=1.98, \mathrm{R}^{2}=0.51$

Where NEER represents nominal effective exchange rate of RMB, tests indicate that every parameter in expression (8) has significance, and goodness of fittest is high. So the equation (8) is rational, and it implies that SV2f increase with the depreciation rate of RMB exchange rate $\triangle$ LNNEER, that is to say, appreciation of the RMB would cause the decrease of SV2f, a larger absolute value of SV2f or with more losses of nfar, the relation between SV2f and $\triangle$ LNNEER are shown in Figure 4.

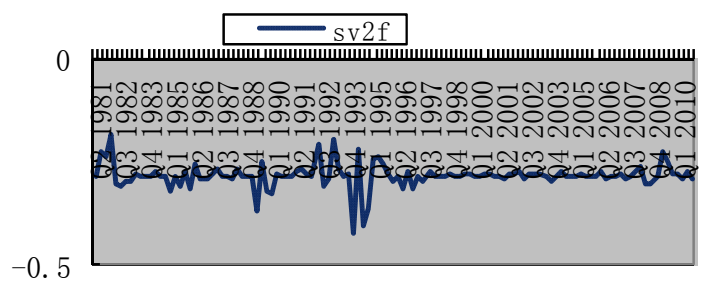

Figure 3. 1981:1-2010:4 quarterly dynamic valuation trend of China's nfar.

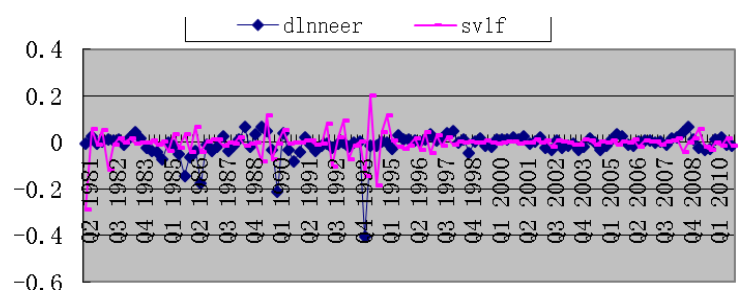

Figure 4. 1981:1-2010:4 RMB NEER and valuation of China's nfar. 


\section{Conclusions}

This paper assesses the valuation effects of China's external wealth since 1981. Building on the intertemporal theoretical framework of Gourinchas and Rey (2005), using Vector Error Correction Model and time-varying Space State Model, it estimates the return and factors of China's net foreign assets.

Historically, I find a substantial part of negative valuation on China's net foreign assets and its sub-category, "risk assets". These valuation effects occur at short to medium horizons, especially at one year to two years.

The fluctuation of international financial assets and exchange rate have played important role in my analysis. Financial crisis and appreciation of RMB deteriorated the return of China's net foreign assets and thereby contribute to the losses of external wealth, implying much wealth outflow through international financial market. So adjust external investment strategies, stabilize the exchange rate of RMB, and push forward RMB internationalization actively are the keys of improve management of Chinese external assets.

\section{REFERENCES}

[1] L. B. Smaghi, "Global Imbalances and Monetary Policy,"Journal of Policy Modeling, Vol. 29, No. 5, 2007, pp. 711-727.doi:10.1016/j.jpolmod.2007.06.008

[2] P. Lane and G. M. Milesi-Ferretti, "The External Wealth of Nations: Measures of Foreign Assets and Liabilities for Industrial and Developing Countries," Journal of International Economics, Vol. 55, No. 2, 2001, pp. 263-294. doi:10.1016/S0022-1996(01)00102-7

[3] P. Lane and G. M. Milesi-Ferretti, "Where did all the Borrowing Go? A Forensic Analysis of the U.S. External Position," J. Japanese Int. Economies, Vol. 23, 2009, pp. 177-199.

[4] P. Th. Konstan, "Adjustment of US External Imbalances: At what horizon?" Economics Letters, Vol. 106, No. 3, 2010, pp. $166-168$.

[5] Gourinchas, Pierre-oliver and H. Rey, "International Financial Adjustment,” NBER Working Paper, 2005.

[6] IMF, "Globalization and External Imbalance," World Economic Outlook, 2005.

[7] P. Lane and G. M. Milesi-Ferretti, "A global Perspective on External Positions," In: Clarida, R. (Ed.), G7 Current Account Imbalances: Sustainability and Adjustment. The University of Chicago Press, Chicago, 2007, pp. 67-98. doi:10.7208/chicago/9780226107288.003.0003

[8] P. Lane and G. M. Milesi-Ferretti, "The External Wealth of Nations Mark II: Revised and Extended Estimates of Foreign Assets and Liabilities, 1970-2004,"Journal of International Economics, Vol. 73, No. 2, 2007, pp. 223-250. doi:10.1016/j.jinteco.2007.02.003

[9] P. Lane and G. M. Milesi-Ferretti, "External Wealth, the Trade Balance, and the Real Exchange Rate," European Economic Review, Vol. 46, No. 6, 2002, pp. 1049-1071. doi:10.1016/S0014-2921(02)00160-5 